\title{
Frequency of Epidermal Growth Factor Receptor Mutation in Smokers with Lung Cancer Without Pulmonary Emphysema
}

\author{
KENICHI TAKEDA ${ }^{1}$, AKIRA YAMASAKI $^{1}$, TADASHI IGISHI ${ }^{1}$, YUJI KAWASAKI $^{1,2}$, \\ SHIZUKA ITO-NISHII ${ }^{1}$, HIROKI IZUMI ${ }^{1}$, TOMOHIRO SAKAMOTO ${ }^{1}$, HIROKAZU TOUGE $^{1}$, \\ MASAHIRO KODANI ${ }^{1}$, HARUHIKO MAKINO ${ }^{1}$, MASAAKI YANAI $^{1}$, NATSUMI TANAKA $^{1}$, \\ SHINGO MATSUMOTO ${ }^{3,4}$, KUNIO ARAKI ${ }^{5}$, HIROSHIGE NAKAMURA ${ }^{5}$ and EIJI SHIMIZU ${ }^{1}$ \\ ${ }^{1}$ Division of Medical Oncology and Molecular Respirology, Department of Multidisciplinary Internal Medicine, \\ Faculty of Medicine, Tottori University, Yonago, Japan; \\ ${ }^{2}$ Tsuyama Daiichi Hospital, Tsuyama, Japan; \\ ${ }^{3}$ Translational Research Unit, Exploratory Oncology Research and Clinical Trial Center, \\ National Cancer Center, Kashiwa, Japan; \\ ${ }^{4}$ Department of Thoracic Oncology, National Cancer Center Hospital East, Kashiwa, Japan; \\ ${ }^{5}$ Division of General Thoracic Surgery, Tottori University Hospital, Yonago, Japan
}

\begin{abstract}
Background: Chronic obstructive pulmonary disease is a smoking-related disease, and is categorized into the emphysema and airway dominant phenotypes. We examined the relationship between emphysematous changes and epidermal growth factor receptor (EGFR) mutation status in patients with lung adenocarcinoma. Patients and Methods: The medical records for 250 patients with lung adenocarcinoma were retrospectively reviewed. All patients were categorized into the emphysema or non-emphysema group. Results: Wild-type EGFR was detected in 136 (54\%) and mutant EGFR in 48 (19\%). Emphysematous changes were observed in $87(36 \%)$ patients. EGFR mutation was highly frequent in the non-emphysema group ( $p=0.0014)$. Multivariate logistic regression analysis showed that emphysema was an independent risk factor for reduced frequency of EGFR mutation (Odds Ratio=3.47, $p=0.005$ ). Conclusion: Our data showed a relationship between emphysematous changes and EGFR mutation status. There might be mutually exclusive genetic risk factors for carcinogenesis and development of emphysematous changes.
\end{abstract}

This article is freely accessible online.

Correspondence to: Kenichi Takeda, 36-1 Nishi-cho, Yonago, Tottori, Japan. Tel: +81 859386537, Fax: +81 859386539, e-mail: takedake@med.tottori-u.ac.jp

Key Words: Epidermal growth factor receptor (EGFR), EGFR mutation, pulmonary emphysema, computed tomographic scans, smoking.
Lung cancer is the leading cause of death in the United States and Japan $(1,2)$. The current prognosis for patients with advanced lung cancer is unsatisfactory even with chemoradiotherapy. Several molecular-targeted agents have been used in the clinical setting and have yielded improved prognoses for advanced lung cancer, especially in patients with somatic mutations in the kinase domain of the epidermal growth factor receptor $(E G F R)$ gene by EGFRtyrosine kinase inhibitors $(3,4)$.

$E G F R$ mutation is frequently observed in patients who are East Asian, female, non-smokers, and diagnosed with adenocarcinoma $(5,6)$. Regarding smoking status, Pham et $a l$. reported that smoking history may be a predictor of lowfrequency $E G F R$ mutation (7). Jida et al. also reported that the cumulative smoking dose and frequency of $E G F R$ mutation status are negatively correlated in Japanese patients with non-small-cell lung carcinoma (8). Therefore, EGFR mutation is regarded as an oncogenic driver mutation of lung cancer in non-smokers and light smokers $(9,10)$. The frequency of $E G F R$ mutations in patients with lung cancer who are non-smokers or light smokers was reported to be $11-43.5 \%(8,10-12)$. However, the reason for the low frequency in patients with lung cancer who smoke remains unclear.

Chronic obstructive pulmonary disease (COPD) is characterized by persistent airflow limitation and chronic inflammatory reactions in the airways and lung in response to noxious particles or gases. Cigarette smoking is the major risk factor for the development and progression of COPD (13-15). Cigarette smoke contains toxic chemicals and causes inflammation in the lung. The characteristic chronic airflow limitation observed in COPD is caused by a mixture 
of diseases of the small airways (obstructive bronchiolitis) and parenchymal destruction (emphysema), the relative contributions of which vary among individuals (16). COPD is commonly observed in patients with lung cancer who are habitual cigarette smokers (17). Regardless of cumulative smoking dose, patients with chronic airflow obstruction have a greater risk for lung cancer $(18,19)$. In recent studies addressing the association between emphysema and lung cancer, the presence of emphysema detected using chest computed tomography (CT) in smokers is reported to be an important risk factor for lung cancer and poor prognosis (2025). Thus, we hypothesized that genetic abnormality, including driver mutations, in lung cancer may differ according to the presence or absence of emphysema even in patients with the same histological type of cancer. In the present study, we evaluated the association between emphysematous changes in the lung parenchyma and EGFR mutation status in patients with lung adenocarcinoma with a history of cigarette smoking.

\section{Patients and Methods}

Patients and data collection. The medical records of 250 patients who visited Tottori University Hospital from April 2008 to September 2011 and were diagnosed with lung adenocarcinoma were retrospectively studied.

The EGFR mutation status was studied using clinically obtained samples from transbronchial lung biopsy, pleural effusion, or surgically resected tumors. This study protocol was reviewed and approved by the Ethics Committee of Tottori University. (\#1054) The medical records were reviewed to obtain clinical and demographic data, including sex, age, smoking history, histological results, clinical stage, treatment, and survival.

Measurement of pulmonary function. Pulmonary function tests were performed in all study patients using a flow spirometer (Chestac 33 spirometer: Chest Co., Tokyo, Japan) according to the standards of the American Thoracic Society (26). Forced expiratory volume in one second (FEV1) and forced vital capacity (FVC) were measured. $\% \mathrm{FVC}$ is the $\mathrm{FVC}$ expressed as a percentage of the predicted value for sex and height using reference equations from Baldwin et al. (27). \%FEV1 is the FEV1 expressed as a percentage of the predicted value (28).

EGFR mutation analysis. The presence of EGFR mutations was determined with the peptide nucleic acid-locked nucleic acid PCRInvader method (BML Inc., Tokyo, Japan).

CT imaging protocol. Chest CT scans were performed using a helical CT scanner (Aquilion 64;Toshiba, Tokyo, Japan) while the participants held their breath at full inspiration. The scanning parameters were as follows: tube current, $40 \mathrm{~mA}$ and scan time of 1 second per gantry rotation, $120 \mathrm{kVp}$. Axial images were reconstructed with a high spatial frequency (lung) algorithm at contiguous, 2-mm, non-overlapping intervals. CT images were viewed on a Monochrome LCD (ME355i2) monitor display system (TOTOKU, Tokyo, Japan) using standard lung window settings.
Table I. Patient characteristics $(n=250)$.

\begin{tabular}{lc}
\hline Characteristic & Value \\
\hline Median age (range), years & $70(43-87)$ \\
Gender, $\mathrm{n}$ & $22(9 \%)$ \\
Female & $228(91 \%)$ \\
Male & $46(1.5-165)$ \\
Pack-years, median \pm SD & \\
Pulmonary function, mean \pm SD & $102 \pm 19$ \\
\%VC predicted & $98.8 \pm 22$ \\
$\%$ FEV1 predicted & $71.1 \pm 11$ \\
FEV1/FVC & $173(69 \%)$ \\
Clinical stage, n $(\%)$ & $77(31 \%)$ \\
IA-IIIA & $163(65 \%)$ \\
IIIB, IV & $87(35 \%)$ \\
Chest CT, n (\%) & \\
Non-emphysema & $136(54 \%)$ \\
Emphysema & $48(19 \%)$ \\
EGFR mutation status, n (\%) & $66(26 \%)$ \\
Wild-type & \\
Mutant* & Unknown
\end{tabular}

VC, Vital capacity; FEV1, forced expiratory volume in one second; FVC, forced vital capacity; CT, computed tomography; EGFR, epidermal growth factor receptor. ${ }^{*} E G F R$ mutations: exon 21 L858R $(20+5)$, exon 19 DEL $(17+2)$, minor $(3+1)$.

Assessment of pulmonary emphysema. The severity and distribution of pulmonary emphysema were determined from high-resolution CT scans. All images were interpreted by two expert chest radiologists to assess for the presence of emphysema using validated criteria (29). In brief, the extent of emphysema was graded from 0 to 4 , with a grade of 0 indicating no emphysema and a grade of 4 indicating the presence of emphysema in more than $75 \%$ of the lung. In this study, patients with grade 1 or more were classified as having emphysema and those with grade 0 as having no emphysema.

Statistical analysis. Differences among the categorized groups were compared using the two-sided Fisher's exact test, Mann-Whitney test, or chi-square test. Multivariate logistic regression analysis was used to check for independence to evaluate factors associated with EGFR mutations. Data were analyzed using PASW statistics 18 (SPSS Inc., Chicago, IL, USA) and GraphPad Prism 6 (GraphPad Software Inc., San Diego, CA, USA) software.

\section{Results}

Patient characteristics are shown in Table I. In this study, the majority of the patients were male $(91 \%)$. The median cumulative smoking dose was 46 pack-years. On the basis of the CT findings, we divided the patients into two groups: the non-emphysema group and emphysema group. Herein, 163 patients $(65 \%)$ were categorized into the nonemphysema group and 87 patients (35\%) into the emphysema group. In this study, we surveyed the EGFR mutation status in the patients with lung cancer, but were 
Table II. Comparison of clinical characteristics between patients with and without emphysema.

\begin{tabular}{|c|c|c|c|}
\hline Characteristic & $\begin{array}{c}\text { Without } \\
\text { emphysema } \\
(n=163)\end{array}$ & $\begin{array}{c}\text { With } \\
\text { emphysema } \\
(n=87)\end{array}$ & $p$-Value \\
\hline Median age (range), years & $70(44-87)$ & $70(43-86)$ & $0.76^{\mathrm{b}}$ \\
\hline \multicolumn{4}{|l|}{ Gender, $\mathrm{n}$} \\
\hline Female & 16 & 6 & \\
\hline Male & 147 & 81 & $0.49^{\mathrm{a}}$ \\
\hline Pack-years, median \pm SD & $48 \pm 32$ & $54 \pm 26$ & $0.012^{b}$ \\
\hline \multicolumn{4}{|l|}{ Pulmonary function, mean \pm SD } \\
\hline$\% \mathrm{VC}$ predicted & $103 \pm 19$ & $100 \pm 18$ & $0.22^{b}$ \\
\hline$\%$ FEV1 predicted & $102 \pm 22$ & $93 \pm 22$ & $0.0014^{b}$ \\
\hline FEV1/FVC & $73 \pm 9.5$ & $68 \pm 12$ & $0.0029 b$ \\
\hline FEV1 predicted $>70 \%, \mathrm{n}$ & 148 & 77 & \\
\hline FEV1 predicted $<70 \%, \mathrm{n}$ & 15 & 10 & $0.66^{\mathrm{a}}$ \\
\hline \multicolumn{4}{|l|}{ Clinical stage, $\mathrm{n}$} \\
\hline I-IIIA & 116 & 57 & \\
\hline IIIB-IV & 47 & 30 & $0.39^{a}$ \\
\hline EGFR mutation status, n (\%) & & & $0.0014^{c}$ \\
\hline Wild-type & $76(46 \%)$ & $60(69 \%)$ & 0.0008 * $*$ \\
\hline Mutant & $40(25 \%)$ & $8(9 \%)$ & \\
\hline Unknown & $47(29 \%)$ & $19(22 \%)$ & \\
\hline
\end{tabular}

VC, Vital capacity; FEV1, forced expiratory volume in one second; FVC, forced vital capacity; EGFR, epidermal growth factor receptor.

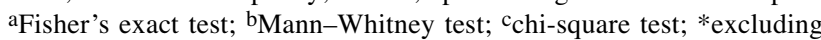
Unknown. Significant values are shown in bold.

unable to obtain the data for 66 (26\%) patients owing to lack of or poor preservation of the samples (Table I).

We next compared the characteristic features of patients with lung cancer between the non-emphysema and emphysema groups (Table II). The cumulative smoking dose as pack-years was significantly higher $(p=0.012)$, and FEV1 (\% predicted value) and FEV1/FVC significantly lower ( $p=0.0014$ and $p=0.0029$, respectively) in the emphysema group. Interestingly, the percentage of EGFR mutation was significantly higher in the non-emphysema group (25\%; $p=0.0014)$. Furthermore, the frequency of $E G F R$ mutation was higher in the non-emphysematous group $(p=0.0008)$. The percentage of EGFR mutation was $34 \%$ in the nonemphysema group and $12 \%$ in the emphysema group.

We next compared pulmonary function between patients with wild-type EGFR and those with mutant EGFR in the non-emphysema group. Although neither the FVC nor FEV1 differed, FEV1/FVC in patients with mutant $E G F R$ was significantly higher than in patients with wild-type $E G F R$ ( $p=0.047$; Table III). Despite the limited comparison within the non-emphysema group, there was a functional difference between the wild-type and mutant groups. We also compared pulmonary function between patients with wild-type $E G F R$ and mutant $E G F R$ in the emphysema group but found no significant difference (data not shown).
Table III. Respiratory function of patients with wild-type and mutant epidermal growth factor receptor (EGFR) without emphysema. Data are the mean $\pm S D$.

\begin{tabular}{lccc}
\hline Pulmonary function & $\begin{array}{c}\text { Wild-type } \\
\text { EGFR }(\mathrm{n}=76)\end{array}$ & $\begin{array}{c}\text { Mutant EGFR } \\
(\mathrm{n}=40)\end{array}$ & $p$-Value* \\
\hline \%VC predicted & $103 \pm 21$ & $104 \pm 16$ & 0.54 \\
\%FEV1 predicted & $99 \pm 24$ & $103 \pm 20$ & 0.41 \\
FEV1/FVC & $71 \pm 10$ & $74 \pm 10$ & $\mathbf{0 . 0 4 7}$ \\
\hline
\end{tabular}

VC, Vital capacity; FEV1, forced expiratory volume in one second; $\mathrm{FVC}$, forced vital capacity. *Mann-Whitney test. Significant values are shown in bold.

Table IV. Comparison of clinical characteristics according to epidermal growth factor receptor (EGFR) status in patients who smoked more than 10 pack-years.

\begin{tabular}{lccc}
\hline Factor & $\begin{array}{c}\text { Wild-type } \\
(\mathrm{n}=133)\end{array}$ & $\begin{array}{c}\text { Mutant } \\
(\mathrm{n}=46)\end{array}$ & $p$-Value \\
\hline $\begin{array}{l}\text { Median age (range), years } \\
\text { Gender, } \mathrm{n}\end{array}$ & $70(46-85)$ & $69.5(44-78)$ & $0.43^{\mathrm{b}}$ \\
$\quad$ Female & 11 & 6 & \\
$\quad$ Male & 122 & 40 & $0.38^{\mathrm{a}}$ \\
Pack-years, median \pm SD & $56 \pm 31$ & $40 \pm 21$ & $\mathbf{0 . 0 0 0 3}^{\mathbf{b}}$ \\
Pulmonary function, mean \pm SD & & & \\
$\quad$ \%VC predicted & $101 \pm 19$ & $104 \pm 16$ & $0.25^{\mathrm{b}}$ \\
\%FEV1 predicted & $96 \pm 23$ & $101 \pm 22$ & $0.11^{\mathrm{b}}$ \\
$\quad$ FEV1/FVC & $69 \pm 12$ & $73 \pm 10$ & $\mathbf{0 . 0 2 1}^{\mathbf{b}}$ \\
Clinical stage; $\mathrm{n}$ & & & \\
IA-IIIA & 80 & 30 & \\
$\quad$ IIIB-IV & 53 & 16 & $0.60^{\mathrm{a}}$ \\
Chest CT; n (\%) & & & \\
$\quad$ No emphysema & $73(55 \%)$ & $38(83 \%)$ & \\
Emphysema & $60(45 \%)$ & $8(17 \%)$ & $\mathbf{0 . 0 0 0 8}^{\mathbf{a}}$ \\
\hline
\end{tabular}

VC, Vital capacity; FEV1, forced expiratory volume in one second;

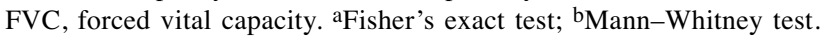
Significant values are shown in bold.

Since the status of EGFR mutation is similar in light smokers and non-smokers, we excluded the data for light smokers $(<10$ pack-years $)$ and examined the clinical characteristics of patients with lung cancer who smoked more than 10 pack-years (Table IV). The clinical parameters were compared between the wild-type and mutant EGFR groups. The cumulative smoking dose was higher (56 vs. 40 pack-years; $p=0.0003$ ) and FEV1/FVC was lower (69\% vs. $73 \% ; p=0.021)$ in the wild-type $E G F R$ group than in the mutant $E G F R$ group. In addition, the rate of emphysema was higher in the wild-type EGFR group than in the mutant EGFR group (45\% vs. 17\%, $p=0.0008)$.

Finally, we conducted a multivariate logistic regression analysis to identify which factors affect the EGFR mutation 
Table V. Multivariate logistic regression analysis of factors associated with epidermal growth factor receptor mutation status.

\begin{tabular}{lccccc}
\hline Factor & Regression coefficient & SE & Odds ratio & $95 \%$ CI & $p$-Value \\
\hline Pack-years & -0.25 & 0.009 & 0.98 & $0.96-0.99$ & $\mathbf{0 . 0 0 4}$ \\
FEV1/FVC & 0.24 & 0.018 & 1.02 & $0.99-1.1$ & 0.172 \\
Absence of emphysema & 1.2 & 0.44 & 3.47 & $1.5-8.2$ & $\mathbf{0 . 0 0 5}$ \\
\hline
\end{tabular}

SE, Standard error; FEV1, forced expiratory volume in one second; FVC, forced vital capacity; CI, confidence interval. Significant values are shown in bold.

status. We set EGFR mutation as a dependent variable and factors that demonstrated statistical differences between the presence and absence of EGFR mutation as independent variables. As shown in Table $\mathrm{V}$, the absence of emphysema (Odds Ratio=3.47, $p=0.005$ ) and smoking dose (odds ratio $=0.98, p=0.004)$ were independently negatively associated with EGFR mutation.

\section{Discussion}

In this study, we showed that the frequency of EGFR mutation was higher in the non-emphysema group than in the emphysema group. Furthermore, we found that the patients with EGFR mutation had better respiratory function, and the absence of emphysema was independently associated with $E G F R$ mutation-positive status in heavy smokers.

Indeed, smoking is one of the most important risk factors for lung cancer (30). However, lung cancer does occur in never-smokers: $10-32.8 \%$ of patients with lung cancer have never smoked (31-34). Several factors, such as environmental tobacco smoke, residential radon, cooking oil vapors, indoor coal and wood burning, viral factors, and genetic factors have been identified as risk factors for lung cancer (33). Recently, lung cancer in never-smokers has been recognized as a separate entity and is classified into non-smoking-associated and smoking-associated lung cancer $(33,34)$. Although the etiology of non-smokingassociated lung cancer remains to be clarified, smokers are estimated to be exposed to the same lung cancer-related risk factors as never-smokers. In heavy smokers, the causes of the lung carcinogenesis are not completely attributable to smoking. Therefore, carcinogenesis related to nonsmoking-associated lung cancer occurs in current and former smokers (35).

Some genetic alterations including $p 53$ point-mutation and KRAS proto-oncogene, GTPase (KRAS) mutation are strongly associated with cigarette smoking in patients with lung cancer (36-38). On the other hand, EGFR mutations and the echinoderm microtubule-associated protein-like 4 anaplastic lymphoma kinase fusion gene $(E M L-A L K)$ are likely to occur in never-smokers $(8,39-41)$. Moreover, smoking itself may not cause EGFR mutation (11). Thus,
EGFR mutation can be regarded as a marker of nonsmoking-associated lung cancer. Since the frequency of EGFR mutations was significantly different between patients with and those without emphysema (Table II), we speculate that the impact of smoking was considerably different between the these two groups in terms of carcinogenesis. The reason why the frequency of EGFR mutations seemed to be low in smokers is that lung cancer in smokers is more likely to include other molecular alterations such as KRAS mutation, serine/threonine kinase $11(L K B I)$ alteration, or DNA methylation $(42,43)$.

In this study, we compared the clinical characteristics of patients with lung cancer, except for those who were light smokers, and found the proportion of those with EGFRmutant status to be significantly higher in the nonemphysema group. The pathophysiology of emphysema can be characterized by the imbalance between proteinases and their inhibitors, increased apoptosis of lung epithelial and endothelial cells, excessive oxidative burden, and inflammatory cell infiltration (44). With respect to the development of emphysema, the impact from smoking varies individually. The reason why all smokers do not develop emphysematous changes has not yet been determined. Betsuyaku et al. showed that neutrophil elastase in alveolar macrophages is related to emphysematous changes in current smokers (45). Although susceptibility factors for the development of emphysematous changes have been studied in genome-wide association studies (46), those associated with emphysema largely depend on host genetics; moreover, susceptibility in terms of not developing emphysema might also depend on host genetics. Some genetic factors related to non-emphysematous changes might be related to carcinogenesis and EGFR mutation status.

In this study, although the smoking dose was higher in the emphysema group than in the non-emphysema group, the difference was less than 6 pack-years, and both groups had smoking doses adequate to cause long-term lung inflammation (Table II). Clinically, even in the non-emphysema group, the smoking dose was sufficient to induce pulmonary emphysema. Nevertheless, the non-emphysema group did not develop CTdetectable emphysema, suggesting that the emphysemainducing mechanism caused by smoking was resolved in the 
non-emphysema group. Thus, the non-emphysema group is regarded to have undefined defensive mechanisms against harmful reactions evoked by smoking. However, the aforementioned mechanisms leading to emphysema can be causes for carcinogenesis or promote tumor growth (47). Given that smoking-induced carcinogenesis depends, at least partially, on emphysema-developing mechanisms, the carcinogenesis risk from smoking should have been relatively low in the non-emphysema group in this study because this group is estimated to be relieved of the emphysema-inducing mechanism caused by smoking. Consequently, a relatively high proportion of cases in the non-emphysema group may be non-smoking-associated lung cancer, and a large proportion in the emphysema group may be smoking-associated.

These speculations are supported by another finding. In the non-emphysema group, patients with EGFR mutation had higher FEV1/FVC values than those with wild-type $E G F R$. This difference is attributable to better airway patency in those with mutant $E G F R$, even in the non-emphysema group. Mutant EGFR lung cancer represents non-smokingassociated lung cancer, and in such patients, smoking may be less carcinogenic to airway parenchyma.

There are many reports about the frequency of EGFR mutation. Smoking history has predictive value for the absence of EGFR mutation, and the frequency of EGFR mutations is inversely associated with cumulative smoking dose $(12,39)$. Our results also showed a similar tendency (Table IV). Interestingly, multivariate analysis showed that both cumulative smoking dose and the absence of emphysema but not FEV1/FVC were independently negatively associated with the frequency of EGFR mutation (Table V). Therefore, we speculate that even in smokers with adenocarcinoma, the presence or absence of CT-detected emphysema has significant value in terms of estimating oncogenic mechanisms and genetic abnormalities, and the absence of emphysema has a predictive value for EGFR mutation.

Clinical implications. We propose that the present results may be valuable in clinical practice. Identification of driver mutations is important to guide treatment strategies for nonsmall-cell lung carcinoma. Since KRAS and EGFR mutations are mutually exclusive as driver mutations $(24,48,49)$, in theory, the frequency of KRAS mutations should be high, especially in patients with emphysema and a history of smoking. Therefore, testing for KRAS mutation may be more appropriate than testing for $E G F R$ mutation in such patients. Once a KRAS mutation has been confirmed, at present, conventional cytotoxic chemotherapeutic agents are selected without further testing for driver mutations. However, since, in the absence of emphysematous changes, the frequency of $E G F R$ mutation increases significantly (Odds Ratio=3.47, $95 \%$ confidence interval $=1.5-8.2$ ) even in patients with a history of smoking, testing for EGFR mutation and probably the $A L K$ fusion gene is recommended. To establish this strategy for driver mutation testing, further studies should determine the frequency of $K R A S$ and $A L K$ fusion genes in smokers with lung adenocarcinoma in the presence and absence of emphysema.

Limitations. This study has some limitations. Firstly, only EGFR mutation status was examined owing to clinical and technical reasons. Evaluation of other genetic abnormalities including $K R A S$ status and $A L K$ fusion is needed to further confirm our speculation in terms of non-smoking-associated lung cancer in smokers. Secondly, we used visual scores to assess the presence and extent of emphysema, although quantitative standardized assessments with computer algorithms can also be used. The advantage of our study is that visual assessment does not require additional software and is simple, and previous studies have shown the validity of this approach (50-53).

\section{Conclusion}

In this study, EGFR mutations were frequently observed in the non-emphysema group, which is characterized by nonsmoking-associated lung cancer. Moreover, the absence of emphysema was independently associated with EGFR mutations. Consequently, the impact of smoking on lung carcinogenesis may differ according to the presence or absence of emphysema among smokers with lung cancer.

\section{References}

1 Siegel R, Ma J, Zou Z and Jemal A: Cancer statistics, 2014. CA Cancer J Clin 64(1): 9-29, 2014.

2 Usui K, Ushijima T, Tanaka Y, Tanai C, Noda H, Abe N, Horiuchi $\mathrm{H}$ and Ishihara $\mathrm{T}$ : The frequency of epidermal growth factor receptor mutation of nonsmall cell lung cancer according to the underlying pulmonary diseases. Pulm Med 2011: 290132, 2011.

3 Mitsudomi T, Kosaka T, Endoh H, Horio Y, Hida T, Mori S, Hatooka S, Shinoda M, Takahashi T and Yatabe Y: Mutations of the epidermal growth factor receptor gene predict prolonged survival after gefitinib treatment in patients with non-small-cell lung cancer with postoperative recurrence. J Clin Oncol 23(11): 2513-2520, 2005.

4 Toyooka S, Takano T, Kosaka T, Hotta K, Matsuo K, Ichihara S, Fujiwara Y, Soh J, Otani H, Kiura K, Aoe K, Yatabe Y, Ohe Y, Mitsudomi T and Date H: Epidermal growth factor receptor mutation, but not sex and smoking, is independently associated with favorable prognosis of gefitinib-treated patients with lung adenocarcinoma. Cancer Sci 99(2): 303-308, 2008.

5 Shigematsu H, Lin L, Takahashi T, Nomura M, Suzuki M, Wistuba, II, Fong KM, Lee H, Toyooka S, Shimizu N, Fujisawa T, Feng Z, Roth JA, Herz J, Minna JD and Gazdar AF: Clinical and biological features associated with epidermal growth factor receptor gene mutations in lung cancers. J Natl Cancer Inst 97(5): 339-346, 2005. 
6 Gazdar AF: Activating and resistance mutations of egfr in nonsmall-cell lung cancer: Role in clinical response to egfr tyrosine kinase inhibitors. Oncogene 28(Suppl 1): S24-31, 2009.

7 Pham D, Kris MG, Riely GJ, Sarkaria IS, McDonough T, Chuai S, Venkatraman ES, Miller VA, Ladanyi M, Pao W, Wilson RK, Singh B and Rusch VW: Use of cigarette-smoking history to estimate the likelihood of mutations in epidermal growth factor receptor gene exons 19 and 21 in lung adenocarcinomas. J Clin Oncol 24(11): 1700-1704, 2006.

8 Jida M, Toyooka S, Mitsudomi T, Takano T, Matsuo K, Hotta K, Tsukuda K, Kubo T, Yamamoto H, Yamane M, Oto T, Sano Y, Kiura K, Yatabe Y, Ohe Y, Date H and Miyoshi S: Usefulness of cumulative smoking dose for identifying the egfr mutation and patients with non-small-cell lung cancer for gefitinib treatment. Cancer Sci 100(10): 1931-1934, 2009.

9 Ren JH, He WS, Yan GL, Jin M, Yang KY and Wu G: Egfr mutations in non-small-cell lung cancer among smokers and nonsmokers: A meta-analysis. Environ Mol Mutagen 53(1): 78-82, 2012.

10 Li H, Pan Y, Li Y, Li C, Wang R, Hu H, Zhang Y, Ye T, Wang L, Shen L, Sun Y and Chen H: Frequency of well-identified oncogenic driver mutations in lung adenocarcinoma of smokers varies with histological subtypes and graduated smoking dose. Lung Cancer 79(1): 8-13, 2013.

11 Matsuo K, Ito H, Yatabe Y, Hiraki A, Hirose K, Wakai K, Kosaka T, Suzuki T, Tajima K and Mitsudomi T: Risk factors differ for non-small-cell lung cancers with and without egfr mutation: Assessment of smoking and sex by a case-control study in japanese. Cancer Sci 98(1): 96-101, 2007.

12 Dogan S, Shen R, Ang DC, Johnson ML, D'Angelo SP, Paik PK, Brzostowski EB, Riely GJ, Kris MG, Zakowski MF and Ladanyi M: Molecular epidemiology of egfr and kras mutations in 3,026 lung adenocarcinomas: Higher susceptibility of women to smoking-related kras-mutant cancers. Clin Cancer Res 18(22): 6169-6177, 2012.

13 Svanes C, Sunyer J, Plana E, Dharmage S, Heinrich J, Jarvis D, de Marco R, Norback D, Raherison C, Villani S, Wjst M, Svanes $\mathrm{K}$ and Anto JM: Early life origins of chronic obstructive pulmonary disease. Thorax 65(1): 14-20, 2010.

14 Postma DS, Kerkhof M, Boezen HM and Koppelman GH: Asthma and chronic obstructive pulmonary disease: Common genes, common environments? Am J Respir Crit Care Med 183(12): 1588-1594, 2011

15 de Marco R, Accordini S, Marcon A, Cerveri I, Anto JM, Gislason T, Heinrich J, Janson C, Jarvis D, Kuenzli N, Leynaert B, Sunyer J, Svanes C, Wjst M and Burney P: Risk factors for chronic obstructive pulmonary disease in a european cohort of young adults. Am J Respir Crit Care Med 183(7): 891-897, 2011.

16 Lundback B, Lindberg A, Lindstrom M, Ronmark E, Jonsson AC, Jonsson E, Larsson LG, Andersson S, Sandstrom T and Larsson K: Not 15 but $50 \%$ of smokers develop copd? - report from the obstructive lung disease in northern sweden studies. Respir Med 97(2): 115-122, 2003.

17 Harada T, Yamasaki A, Fukushima T, Hashimoto K, Takata M, Kodani M, Okazaki R, Takeda K, Watanabe M, Kurai J and Shimizu E: Causes of death in patients with asthma and asthmachronic obstructive pulmonary disease overlap syndrome. Int J Chron Obstruct Pulmon Dis 10: 595-602, 2015.

18 Skillrud DM, Offord KP and Miller RD: Higher risk of lung cancer in chronic obstructive pulmonary disease. A prospective, matched, controlled study. Ann Intern Med 105(4): 503-507, 1986.
19 Tockman MS, Anthonisen NR, Wright EC and Donithan MG: Airways obstruction and the risk for lung cancer. Ann Intern Med 106(4): 512-518, 1987.

20 Ueda K, Jinbo M, Li TS, Yagi T, Suga K and Hamano K: Computed tomography-diagnosed emphysema, not airway obstruction, is associated with the prognostic outcome of earlystage lung cancer. Clin Cancer Res 12(22): 6730-6736, 2006.

21 de Torres JP, Bastarrika G, Wisnivesky JP, Alcaide AB, Campo A, Seijo LM, Pueyo JC, Villanueva A, Lozano MD, Montes U, Montuenga L and Zulueta JJ: Assessing the relationship between lung cancer risk and emphysema detected on low-dose ct of the chest. Chest 132(6): 1932-1938, 2007.

22 Maldonado F, Bartholmai BJ, Swensen SJ, Midthun DE, Decker PA and Jett JR: Are airflow obstruction and radiographic evidence of emphysema risk factors for lung cancer? A nested case-control study using quantitative emphysema analysis. Chest 138(6): 1295-1302, 2010

23 Li Y, Swensen SJ, Karabekmez LG, Marks RS, Stoddard SM, Jiang R, Worra JB, Zhang F, Midthun DE, de Andrade M, Song $\mathrm{Y}$ and Yang P: Effect of emphysema on lung cancer risk in smokers: A computed tomography-based assessment. Cancer Prev Res (Phila) 4(1): 43-50, 2011.

24 Ding L, Getz G, Wheeler DA, Mardis ER, McLellan MD, Cibulskis K, Sougnez C, Greulich H, Muzny DM, Morgan MB, Fulton L, Fulton RS, Zhang Q, Wendl MC, Lawrence MS, Larson DE, Chen K, Dooling DJ, Sabo A, Hawes AC, Shen H, Jhangiani SN, Lewis LR, Hall O, Zhu Y, Mathew T, Ren Y, Yao J, Scherer SE, Clerc K, Metcalf GA, Ng B, Milosavljevic A, Gonzalez-Garay ML, Osborne JR, Meyer R, Shi X, Tang Y, Koboldt DC, Lin L, Abbott R, Miner TL, Pohl C, Fewell G, Haipek C, Schmidt H, Dunford-Shore BH, Kraja A, Crosby SD, Sawyer CS, Vickery T, Sander S, Robinson J, Winckler W, Baldwin J, Chirieac LR, Dutt A, Fennell T, Hanna M, Johnson BE, Onofrio RC, Thomas RK, Tonon G, Weir BA, Zhao X, Ziaugra L, Zody MC, Giordano T, Orringer MB, Roth JA, Spitz MR, Wistuba, II, Ozenberger B, Good PJ, Chang AC, Beer DG, Watson MA, Ladanyi M, Broderick S, Yoshizawa A, Travis WD, Pao W, Province MA, Weinstock GM, Varmus HE, Gabriel SB, Lander ES, Gibbs RA, Meyerson M and Wilson RK: Somatic mutations affect key pathways in lung adenocarcinoma. Nature 455(7216): 1069-1075, 2008.

25 Adcock IM, Caramori G and Barnes PJ: Chronic obstructive pulmonary disease and lung cancer: New molecular insights. Respiration 81(4): 265-284, 2011.

26 Standardization of spirometry, 1994 update. American thoracic society. Am J Respir Crit Care Med 152(3): 1107-1136, 1995.

27 Baldwin ED, Cournand A and Richards DW, Jr.: Pulmonary insufficiency; physiological classification, clinical methods of analysis, standard values in normal subjects. Medicine (Baltimore) 27(3): 243-278, 1948.

28 Berglund E, Birath G, Bjure J, Grimby G, Kjellmer I, Sandqvist $\mathrm{L}$ and Soderholm B: Spirometric studies in normal subjects. I. Forced expirograms in subjects between 7 and 70 years of age. Acta Med Scand 173: 185-192, 1963.

29 National Emphysema Treatment Trial Research Group: Patients at high risk of death after lung-volume-reduction surgery. $\mathrm{N}$ Engl J Med 345(15): 1075-1083, 2001.

30 Toh CK, Wong EH, Lim WT, Leong SS, Fong KW, Wee J and Tan EH: The impact of smoking status on the behavior and survival outcome of patients with advanced non-small cell lung cancer: A retrospective analysis. Chest 126(6): 1750-1756, 2004. 
31 Parkin DM, Bray F, Ferlay J and Pisani P: Global cancer statistics, 2002. CA Cancer J Clin 55(2): 74-108, 2005.

32 Toh CK, Gao F, Lim WT, Leong SS, Fong KW, Yap SP, Hsu AA, Eng P, Koong HN, Thirugnanam A and Tan EH: Neversmokers with lung cancer: Epidemiologic evidence of a distinct disease entity. J Clin Oncol 24(15): 2245-2251, 2006.

33 Sun S, Schiller JH and Gazdar AF: Lung cancer in never smokers a different disease. Nat Rev Cancer 7(10): 778-790, 2007.

34 Yano T, Miura N, Takenaka T, Haro A, Okazaki H, Ohba T, Kouso H, Kometani T, Shoji F and Maehara Y: Never-smoking nonsmall cell lung cancer as a separate entity: Clinicopathologic features and survival. Cancer 113(5): 1012-1018, 2008.

35 Yano T, Haro A, Shikada Y, Maruyama R and Maehara Y: Nonsmall cell lung cancer in never smokers as a representative 'nonsmoking-associated lung cancer': Epidemiology and clinical features. Int J Clin Oncol 16(4): 287-293, 2011.

36 Ahrendt SA, Decker PA, Alawi EA, Zhu Yr YR, SanchezCespedes M, Yang SC, Haasler GB, Kajdacsy-Balla A, Demeure MJ and Sidransky D: Cigarette smoking is strongly associated with mutation of the k-ras gene in patients with primary adenocarcinoma of the lung. Cancer 92(6): 1525-1530, 2001.

37 Pfeifer GP, Denissenko MF, Olivier M, Tretyakova N, Hecht SS and Hainaut P: Tobacco smoke carcinogens, DNA damage and p53 mutations in smoking-associated cancers. Oncogene 21(48): 7435-7451, 2002.

38 Suzuki M, Shigematsu H, Iizasa T, Hiroshima K, Nakatani Y, Minna JD, Gazdar AF and Fujisawa T: Exclusive mutation in epidermal growth factor receptor gene, her-2, and kras, and synchronous methylation of nonsmall cell lung cancer. Cancer 106(10): 2200-2207, 2006.

39 Kosaka T, Yatabe Y, Endoh H, Kuwano H, Takahashi T and Mitsudomi T: Mutations of the epidermal growth factor receptor gene in lung cancer: Biological and clinical implications. Cancer Res 64(24): 8919-8923, 2004.

40 Buttitta F, Barassi F, Fresu G, Felicioni L, Chella A, Paolizzi D, Lattanzio G, Salvatore S, Camplese PP, Rosini S, Iarussi T, Mucilli F, Sacco R, Mezzetti A and Marchetti A: Mutational analysis of the her2 gene in lung tumors from caucasian patients: Mutations are mainly present in adenocarcinomas with bronchioloalveolar features. Int J Cancer 119(11): 2586-2591, 2006.

41 Shaw AT, Yeap BY, Mino-Kenudson M, Digumarthy SR, Costa DB, Heist RS, Solomon B, Stubbs H, Admane S, McDermott U, Settleman J, Kobayashi S, Mark EJ, Rodig SJ, Chirieac LR, Kwak EL, Lynch TJ and Iafrate AJ: Clinical features and outcome of patients with non-small-cell lung cancer who harbor eml4-alk. J Clin Oncol 27(26): 4247-4253, 2009.

42 Toyooka S, Maruyama R, Toyooka KO, McLerran D, Feng Z, Fukuyama Y, Virmani AK, Zochbauer-Muller S, Tsukuda K, Sugio K, Shimizu N, Shimizu K, Lee H, Chen CY, Fong KM, Gilcrease M, Roth JA, Minna JD and Gazdar AF: Smoke exposure, histologic type and geography-related differences in the methylation profiles of non-small cell lung cancer. Int $\mathbf{J}$ Cancer 103(2): 153-160, 2003.

43 Matsumoto S, Iwakawa R, Takahashi K, Kohno T, Nakanishi Y, Matsuno Y, Suzuki K, Nakamoto M, Shimizu E, Minna JD and Yokota J: Prevalence and specificity of $1 \mathrm{~kb} 1$ genetic alterations in lung cancers. Oncogene 26(40): 5911-5918, 2007.

44 Taraseviciene-Stewart L and Voelkel NF: Molecular pathogenesis of emphysema. J Clin Invest 118(2): 394-402, 2008.
45 Betsuyaku T, Yoshioka A, Nishimura M, Miyamoto K, Kondo T and Kawakami Y: Neutrophil elastase associated with alveolar macrophages from older volunteers. Am J Respir Crit Care Med 151(2 Pt 1): 436-442, 1995.

46 Cho MH, Castaldi PJ, Hersh CP, Hobbs BD, Barr RG, TalSinger R, Bakke P, Gulsvik A, San Jose Estepar R, Van Beek EJ, Coxson HO, Lynch DA, Washko GR, Laird NM, Crapo JD, Beaty TH and Silverman EK: A genome-wide association study of emphysema and airway quantitative imaging phenotypes. Am J Respir Crit Care Med 192(5): 559-569, 2015.

47 Houghton AM: Mechanistic links between copd and lung cancer. Nat Rev Cancer 13(4): 233-245, 2013.

48 Weir BA, Woo MS, Getz G, Perner S, Ding L, Beroukhim R, Lin WM, Province MA, Kraja A, Johnson LA, Shah K, Sato M, Thomas RK, Barletta JA, Borecki IB, Broderick S, Chang AC, Chiang DY, Chirieac LR, Cho J, Fujii Y, Gazdar AF, Giordano T, Greulich H, Hanna M, Johnson BE, Kris MG, Lash A, Lin L, Lindeman N, Mardis ER, McPherson JD, Minna JD, Morgan MB, Nadel M, Orringer MB, Osborne JR, Ozenberger B, Ramos AH, Robinson J, Roth JA, Rusch V, Sasaki H, Shepherd F, Sougnez C, Spitz MR, Tsao MS, Twomey D, Verhaak RG, Weinstock GM, Wheeler DA, Winckler W, Yoshizawa A, Yu S, Zakowski MF, Zhang Q, Beer DG, Wistuba, II, Watson MA, Garraway LA, Ladanyi M, Travis WD, Pao W, Rubin MA, Gabriel SB, Gibbs RA, Varmus HE, Wilson RK, Lander ES and Meyerson M: Characterizing the cancer genome in lung adenocarcinoma. Nature 450(7171): 893-898, 2007.

49 Rikova K, Guo A, Zeng Q, Possemato A, Yu J, Haack H, Nardone J, Lee K, Reeves C, Li Y, Hu Y, Tan Z, Stokes M, Sullivan L, Mitchell J, Wetzel R, Macneill J, Ren JM, Yuan J, Bakalarski CE, Villen J, Kornhauser JM, Smith B, Li D, Zhou $\mathrm{X}$, Gygi SP, Gu TL, Polakiewicz RD, Rush J and Comb MJ: Global survey of phosphotyrosine signaling identifies oncogenic kinases in lung cancer. Cell 131(6): 1190-1203, 2007.

50 Bastarrika G, Garcia-Velloso MJ, Lozano MD, Montes U, Torre W, Spiteri N, Campo A, Seijo L, Alcaide AB, Pueyo J, Cano D, Vivas I, Cosin O, Dominguez P, Serra P, Richter JA, Montuenga L and Zulueta JJ: Early lung cancer detection using spiral computed tomography and positron emission tomography. Am J Respir Crit Care Med 171(12): 1378-1383, 2005.

51 Maisonneuve P, Bagnardi V, Bellomi M, Spaggiari L, Pelosi G, Rampinelli C, Bertolotti R, Rotmensz N, Field JK, Decensi A and Veronesi G: Lung cancer risk prediction to select smokers for screening ct--a model based on the italian cosmos trial. Cancer Prev Res (Phila) 4(11): 1778-1789, 2011.

52 Wilson DO, Leader JK, Fuhrman CR, Reilly JJ, Sciurba FC and Weissfeld JL: Quantitative computed tomography analysis, airflow obstruction, and lung cancer in the pittsburgh lung screening study. J Thorac Oncol 6(7): 1200-1205, 2011.

53 Smith BM, Pinto L, Ezer N, Sverzellati N, Muro S and Schwartzman K: Emphysema detected on computed tomography and risk of lung cancer: A systematic review and meta-analysis. Lung Cancer 77(1): 58-63, 2012.

Received December 1, 2016

Revised January 17, 2017

Accepted January 19, 2017 